\title{
主要ターミナル周辺の景観特性比較から捉えた大阪らしさに関する考察
}

大阪府立大学大学院人間社会システム科学研究科 杉本 真莉 大阪府立大学大学院人間社会システム科学研究科 下村 泰彦

1, はじめに

大阪市は、近年観光都市としての性格を強め、特にキタ と呼ばれる JR 大阪駅を中心とする梅田、ミナミと呼ばれ る地下鉄なんば〜心斎橋駅周辺の難波、という二大繁華街 に加えて、南大阪への玄関口である天王寺の 3 つのエリア が “核”となり、高い集客効果を上げている。これら主要 ターミナルは、大阪市を代表する景観として居住者が認識 しているだけでなく、来訪者にとっても大阪市を印象付け る重要なエリアであるといえる。

現行の大阪市で進められている景観計画では『大都市と しての風格と、集客都市としての大阪らしい魅力があふれ る景観の形成』を目標に、水辺や緑地、歴史的・文化的資 源など地域の特性を活かすような形で施策方針が立てられ るなど、地域らしさの創出・活用がキーワードになってい る 1)。リンチ2)によるとここでの地域らしさ、という意味で のアイデンティティは、ストラクチャー (構造) とともに 都市環境のイメージを構成する要素とされている。大阪市 らしさを維持するようなまちづくりを進めていくためには、 空間構造についてはもちろんのこと、人々が大阪市に対し て抱くイメージ、情緒的評価に関しての知見を反映させる ことも不可欠だと考える。

アイデンティティを扱った既往研究について、木下ら ${ }^{3)}$ は市街地再開発事業に関係するアイデンティティについて、 地域固有の空間資源の活用や運営がその形成に寄与すると の見解を示し、木村 ${ }^{4}$ は人々が愛着を持つに至る空間にお けるアイデンティティ表出について捉えている。また上田 7)は地域が本来持っている地域らしさやアイデンティティ を、まちづくりと、その観光地化に寄与する要素として捉 えている。同様に倉澤ら 5)は主にメディアによって形作ら れる地域イメージが、観光や都市の活性化に対して与える 影響について言及し、鈴木らのは個々の地域に焦点を当て たまちづくりの必要性について、居住者の愛着や関心とい う観点から捉えている。

本研究では、上述した既往研究における地域らしさや 地域イメージと、まちづくり及ひ観光による都市の活性化 との関係性についての知見を参考に、近年観光都市として 存在感を強めている大阪市を対象とし、景観という観点か ら「大阪らしさ」を明らかにしようとするものである。

\section{2, 調査及び解析方法}

(1) 調査対象地域の設定

調査を実施するにあたり、大阪市以外から来訪した場合、 最初に到着するターミナルが大阪らしさをまず印象づける と考えられることから、「梅田」「難波」「天王寺」を主 要3エリアと位置づけ、調査対象地域として設定した。調査
対象範囲はターミナルとなる駅を含み、また該当エリアに 関する観光パンフレットやガイドブックで紹介される主要 なスポットを含むことを条件に調査対象エリアを設定した ため、エリアごとにその面積や形態に違いが生じている。 梅田エリアは、JR大阪駅を含む東西 $1.4 \mathrm{~km}$ 、南北 $1.5 \mathrm{~km}$ 、面 積2.10km²の範囲を設定した。難波エリアは、南海なんば駅及 び地下鉄なんば駅と地下鉄心斎橋駅を含む東西 $0.7 \mathrm{~km}$ 、南 北1.6km、面積1.12km²範囲を設定した。天王寺エリアは、 $\mathrm{JR}$ 天王寺駅及び近鉄阿倍野橋駅を含む東西 $1.2 \mathrm{~km}$ 、南北 $1.4 \mathrm{~km}$ 、面積 $1.68 \mathrm{~km} \mathrm{k}^{2} の$ 範囲を設定した。

(2) 物的環境特性に関する調查

物的環境特性を把握するために、主要3エリア内の建築物 等の開発・更新年、主な利用用途、建物高さに関する文献・ 資料調査を実施した。その後、調査対象エリア内で主に戦 後行われた開発に関する年表を作成し、同時に建物更新年 別土地利用現況図を作成、建築物ごとの分布状況と面積割 合を算出した。建物更新年は～1993年,1994～2000年,2001～ 2009年,2010～2012年,2013～2015年に5区分し、面積計測方 法はPhotoShop Ver,10を用いて、該当建築物のピクセル数を、 全建築物の総ピクセル数で除することにより求め、百分率 表記で示した（表 1 ）。

調査対象エリアの利用特性に関しては、建物主用途別土 地利用現況図を作成し、建物高さの特性に関しては、建物

\section{表 -1 建物更新年別土地利用の割合}

\begin{tabular}{|l|c|c|c|c|c|c|}
\hline \multirow{2}{*}{} & \multicolumn{5}{|c|}{ 更新年 } & \multirow{2}{*}{ 合計(\%) } \\
\cline { 2 - 6 } & $\sim 1993$ & $1994 \sim 2000$ & $2001 \sim 2009$ & $2010 \sim 2012$ & $2013 \sim 2015$ & \\
\hline 梅田 & 35.7 & 11.9 & 24.7 & 15.9 & 11.7 & 100 \\
\hline 難波 & 9.9 & 42.8 & 6.6 & 8.7 & 32.0 & 100 \\
\hline 天王寺 & 16.5 & 20.9 & 15.9 & 12.2 & 34.5 & 100 \\
\hline
\end{tabular}

表 -2 建物用途別土地利用の割合

\begin{tabular}{|c|c|c|c|c|c|c|c|c|c|c|}
\hline & \multicolumn{9}{|c|}{ 建物用途 } & \multirow[b]{2}{*}{ 合計(\%) } \\
\hline & $\begin{array}{l}\text { 住 } \\
\text { 宅 }\end{array}$ & $\begin{array}{l}\text { 商 } \\
\text { 業 }\end{array}$ & \begin{tabular}{|l} 
業 \\
務
\end{tabular} & $\begin{array}{l}\text { サ } \\
\text { I } \\
\text { ビ } \\
\text { ス }\end{array}$ & $\begin{array}{l}\text { 工 } \\
\text { 場 }\end{array}$ & $\begin{array}{l}\text { 供 } \\
\text { 給 } \\
\text { 処 } \\
\text { 理 }\end{array}$ & $\begin{array}{c}\text { 運 } \\
\text { 輸 } \\
\dot{.} \\
\text { 通 } \\
\text { 信 } \\
\end{array}$ & $\begin{array}{l}\text { 官 } \\
\text { 公 } \\
\text { 署 }\end{array}$ & $\begin{array}{c}\text { そ } \\
\text { の } \\
\text { 他 }\end{array}$ & \\
\hline 梅田 & \begin{tabular}{|l|}
7.6 \\
\end{tabular} & 18.8 & 25.6 & 13.1 & 2.0 & \begin{tabular}{|l|}
0.5 \\
\end{tabular} & 16.2 & 2.3 & \begin{tabular}{|l|}
13.9 \\
\end{tabular} & 100 \\
\hline 難波 & \begin{tabular}{|l|}
10.2 \\
\end{tabular} & 32.7 & 19.3 & 18.9 & 6.9 & \begin{tabular}{|l|}
0.2 \\
\end{tabular} & 7.3 & 1.4 & \begin{tabular}{|l|}
3.1 \\
\end{tabular} & 100 \\
\hline 天王寺 & 34.3 & 22.0 & 70 & 12.4 & 12.6 & 0.0 & 7.9 & 1.2 & \begin{tabular}{|l|}
2.6 \\
\end{tabular} & 100 \\
\hline
\end{tabular}

表-3 建物高さ別土地利用の割合

\begin{tabular}{|l|c|c|c|c|c|c|c|c|}
\hline & \multicolumn{7}{|c|}{ 高さ $(\mathrm{m})$} & \multirow{2}{*}{ 合計(\%) } \\
\cline { 2 - 9 } & $\sim 1$ & $\sim 10$ & $\sim 31$ & $\sim 60$ & $\sim 100$ & $\sim 300$ & $\sim 500$ & \\
\hline 梅田 & 2.2 & 10.3 & 15.3 & 23.2 & 18.9 & 30.0 & 0.0 & 100 \\
\hline 難波 & 1.2 & 10.9 & 36.4 & 34.6 & 11.1 & 5.8 & 0.0 & 100 \\
\hline 天王寺 & 2.1 & 36.6 & 19.3 & 26.2 & 9.9 & 2.8 & 3.1 & 100 \\
\hline
\end{tabular}


高さ別土地利用現況図を作成した。その後、建築物ごとに 主用途と高さそれぞれについて、その分布状況と面積割合 を把握した。建物主用途は「住宅」「商業」「業務」「サ ービス」「工場」「供給処理」「運輸・通信」「官公署」

「その他」に9区分している（表 2）。建物高さは〜 $1 \mathrm{~m}, 1 \mathrm{~m}$ $\sim 10 \mathrm{~m}, 10 \mathrm{~m} \sim 31 \mathrm{~m}, 31 \mathrm{~m} \sim 60 \mathrm{~m}, 60 \mathrm{~m} \sim 100 \mathrm{~m}, 100 \mathrm{~m} \sim 300 \mathrm{~m}$ に 6 区分している（表3）。なお、面積計測は建物更新年に関 する調査と同様に行った。

（3）情緒的評価に関する意識調査

意識調查は、大阪市主要 3 エリアの景観写真を刺激媒体 として本学現代システム科学域環境システム学類 2 年〜 4年 の学生62人の被験者を対象に実施した $(\mathrm{H} 27,10)$ 。景観写真 については、複数の観光ガイドブックに掲載された写真を 各エリア 8 景、計 24 景を調査対象景として抽出し、現地にて 同一視点・視対象の写真を撮影した $(\mathrm{H} 27,8)$ 。調查の実施は、 主要3エリアの景観写真を各エリア8枚ずつ、合計24枚被験 者に提示し、情緒的評価項目に対して5段階で評価の記入を 求めた。評定内容は18対の形容詞対からなる情緒的評価項 目で構成し、具体的には「かたい↔やわらかい」「おとな しい↔活発な」「醜い↔美しい」「騒々しい↔のどかな」

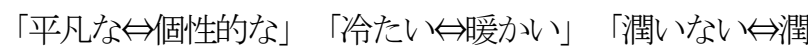
いある」「重苦しい↔軽快な」「暗い↔明るい」「野暮な ↔洗練された」「落ち着かない↔落ち着く」「弱々しい↔ 力強い」「単調な $\Leftrightarrow$ 変化の ある」「平面的な乡立体感 のある」「点在した↔密集 した」「人工的な $\Leftrightarrow$ 自然的 な」閉鎖的な乡開放的な」

「ばらばらな乡統一感の ある」である。調査では5 段階の評価尺度 (非常に、 やや、どちらでもない や や、非常に）を用いてその

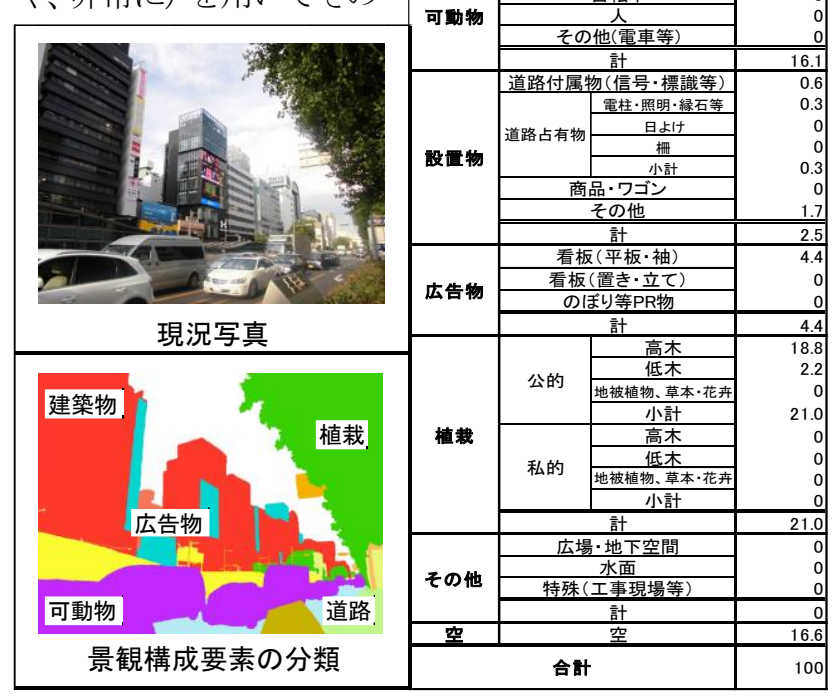

図-1 景観構成要素の解析方法（事例 難波 No1）
中から選択することを求めた。

解析では、エリア別に 5 段階の評価尺度にそれぞれ+2〜 -2 の評価点を与えて、基礎データを作成した。次に景観 刺激写真別に各評価項目の平均評価点を算出し、これらの データを用いて、因子分析法を適用した。その結果、因子 の固有值が 1.000 以上であり、かつ累積寄与率が $70 \%$ 以上 を占めるまでを採用するものとした。因子の意味づけでは、 第 1 及び第 2 因子毎に因子負荷量が 0.700 以上の項目を用 いた。さらに各エリア 8 景の因子得点を用いて第 1 因子を $\mathrm{X}$ 軸、第 2 因子をY軸とした 2 次元布置図を作成し、階層 的クラスター分析 (群平均法) を適用、同エリア内の 8 景 を類型化した。この結果を用いて各タイプの布置状況を参 考にして各タイプに名称をつけ、景観評価構造を把握した。

\section{(4) 景観構成に関する調查}

各エリア8枚、合計24枚の景観写真をPhotoShop Ver,10で 読み取り加工した後、景観構成要素の画面占有率を計測し た。景観構成要素は、道路 (車道, 歩道)、建築物（低層, 中層, 高層, 超高層, その他) 、構造物（歩道橋・高架, アーケード，階段，その他）、可動物（自動車，自転車， 人, 電車等) 、設置物（道路付属物，道路占有物，商品 ワゴン，その他）、広告物（平板・袖看板，立て・置き看 板, のぼり等PR物)、植栽 (公的, 私的, 高木, 低木, 地 被植物・草本花卉）、その他、空とした(図 1)。画面構成 率は、景観構成要素のピクセル数を、全景観構成要素の総 ピクセル数で除することにより求め、百分率表記で示した。 その後、階層的クラスター分析によって類型化された各エ リアのタイプ別に、景観構成要素の占有率について把握し、 各タイプの景観特性の特徴を捉えた（図2）。

\section{3, 解析結果及び考察}

\section{(1) 梅田らしさの解明}

梅田エリアにおいては、主に 1994〜2015 年の約 20 年 の間に全体の 6 割以上の建物が更新されている。また、 1994 年以降の開発によって建設された建物は一敷地当 たりの面積規模が大きいところに特徴がある。これらの 建物は主に商業系用途々業務系用途に使用されており、

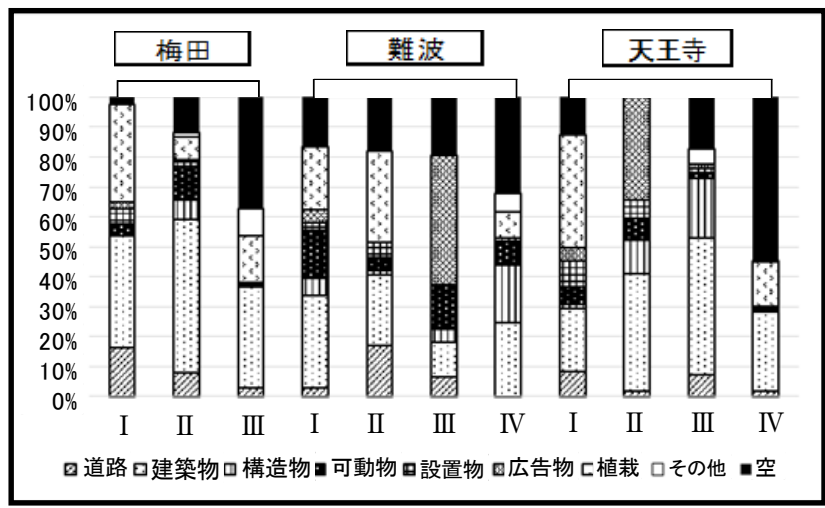

図-2 景観構成要素の画面占有率 
特にターミナル駅の周辺は商業系用途の建物が目立ち、 近年の開発が同エリアの高層ビル群を形成している。一方 1993 年までに更新された建物は低層・中層建築が多く、タ 一ミナル駅周辺の比較的新しい建物のみが突出しているよ うな景観を呈していると考えられる。梅田エリアでは近年 の開発事業による、斬新なデザインの建築物群が創造され るといった急激な景観の変化があったものと考えられる。

因子分析の結果、第 1 因子を『都市的快適性』、第 2 因子 を『立体感』と判断し、8 景を 3 タイプ( I III)に分類でき た (図 3$)$ 。 I は立体感があり潤いに満ちたタイプであり、 可動物や文字や色彩が目立つ広告物があまり見られず、奥 行きと落ち着きのある景観を呈している。 IIは潤いを感じ られるタイプであり、壁面位置の統一が連続的イメージを 形成し、広範囲の植栽の存在が潤い性を助長している。 III は平坦で閏いに乏しいタイプであり、人工的な印象が目立 つ景観が形成され、植栽の少なさが潤い性を低くしている。

梅田エリアでは 1994 年以降の開発事業による急激な景 観変化がみられ、先進性のある更新に伴う高い都市的快適 性を備えている。私的植栽の多さからも、90 年代以降の都 市開発において重要視される都市の緑化に対する高い意識 を伺うことができ、梅田エリア全体が先進性をもつた比較 的新しいエリアであることを物語っている。また、ターミ ナル駅周辺での超高層建築の多さが『立体感』のイメージ 形成に寄与していた。

\section{(2) 難波らしさの解明}

難波エリアにおいては、主に 1994～2015 年の約 20 年の 間に全体の約 7 割もの建物が更新されている。特に 2001 年 〜2009 年の間に約 5 割程度の更新が行われ、同エリアの特 にターミナル駅である南海難波駅周辺と御堂筋沿道の景観 に急激な変化をもたらしたと考えられる。これらの建物は 主に商業系用途と業務系用途、サービス系用途に使用され ているが、南海難波駅の周辺には住宅系用途の建物も目立 つところに特徴がある。一方隣接する区域では 1993 年ま でに更新されている低層・中層建築が多く位置している。

表－4 因子分析による 3 エリアの地域特性

\begin{tabular}{|c|c|c|c|c|c|c|}
\hline \multirow{3}{*}{ 情緒的語句 } & \multicolumn{2}{|c|}{ 梅田 } & \multicolumn{2}{|c|}{ 難波 } & \multicolumn{2}{|c|}{ 天王寺 } \\
\hline & 第1因子 & 第2因子 & 第1因子 & 第2因子 & 第1因子 & 第2因子 \\
\hline & 都市的快適性 & 立体感 & 都市的快適性 & 快活性 & 都市的快適性 & 生活感 \\
\hline 柔らかさ & 0.943 & 0.015 & 0.503 & 0.777 & -0.120 & 0.991 \\
\hline 产 & -0.891 & -0.138 & -0.900 & 0.274 & 0.984 & -0.115 \\
\hline 美 & 0.884 & 0.400 & 0.969 & -0.020 & -0.944 & -0219 \\
\hline 动さ & [ 0.881 & 0.382 & 0.984 & -0.070 & -0.926 & 0.362 \\
\hline & 0.078 & 0.845 & -0.520 & 0.642 & 口 0.846 & -0.106 \\
\hline 暖かさ & च 0.976 & 0.064 & 0.079 & 口 0.835 & 0.169 & — 0.941 \\
\hline 潤い & 0.855 & 0.317 & 0.862 & 0.501 & -0.810 & 0.456 \\
\hline & च 0.951 & 0.18 & 0.368 & 0.887 & -0.606 & 0.627 \\
\hline & 0.884 & 0.182 & 0.066 & 0.984 & -0.702 & -0.027 \\
\hline 洗 & 0.653 & 0.694 & 0.962 & 0.122 & -0.869 & -0.494 \\
\hline 着き & 0.962 & 0.259 & 0.977 & 0.066 & -0.940 & 0.327 \\
\hline 力強さ & -0.811 & 0.426 & -0.960 & 0.047 & 口 0.709 & -0.350 \\
\hline & 0.518 & 0.611 & -0.515 & च 0.852 & 0.671 & 0.026 \\
\hline 立体感 & -0.085 & 0.755 & -0.198 & 0.658 & -0.021 & -0.506 \\
\hline 密集 & -0.626 & -0.555 & -0.967 & 0.087 & 口 0.956 & -0.189 \\
\hline 自然 & 0.904 & 0.095 & 0.962 & 0.101 & -0.660 & 0.744 \\
\hline 開放的 & 0.792 & 0.502 & 0.910 & 0.327 & -0.904 & 0.179 \\
\hline 統一感 & 0.364 & 0.119 & 0.921 & -0.247 & -0.842 & -0.328 \\
\hline 固有値 & $\overline{12}$ & 2.57 & 10.85 & 5.31 & 11.02 & 3.85 \\
\hline 寄与率 & $66.88 \%$ & $14.25 \%$ & $60.29 \%$ & $29.48 \%$ & $61.20 \%$ & $21.38 \%$ \\
\hline 累積寄与率 & $66.88 \%$ & $81.13 \%$ & $60.29 \%$ & $89.77 \%$ & $61.20 \%$ & $82.59 \%$ \\
\hline
\end{tabular}

特に工場系用途の建物はこの地区に集中して分布している。 難波エリアでは建設年代や用途、高さ等が異なる様々な形 態の建物が同一エリア内に見られ、これらの建築物が混在 して景観を形成していると考えられる。

因子分析の結果、第 1 因子を『都市的快適性』、第 2 因子 を『快活性』と判断し、8 景を4 タイプ( I IV)に分類でき た (図4)。I は快適性を備え活気と賑わいに満ちたタイプ であり、豊富な植栽と遠景に見える空が景観に奥行きと拡 がり感を醇し出している。人も多く視認され、賑わい性が 確認できる。IIは快適性を欠くが、活気と賑わいに満ちた タイプであり、商品・ワゴン等の設置物や広告物などが多 く存在し、ファサードが雑多で人の密集度も高い。IIIは快 適性を備えるが、活気と賑わいが乏しいタイプであり、建 築物より前面にある植栽が無機質な建物の圧迫感を軽減し、

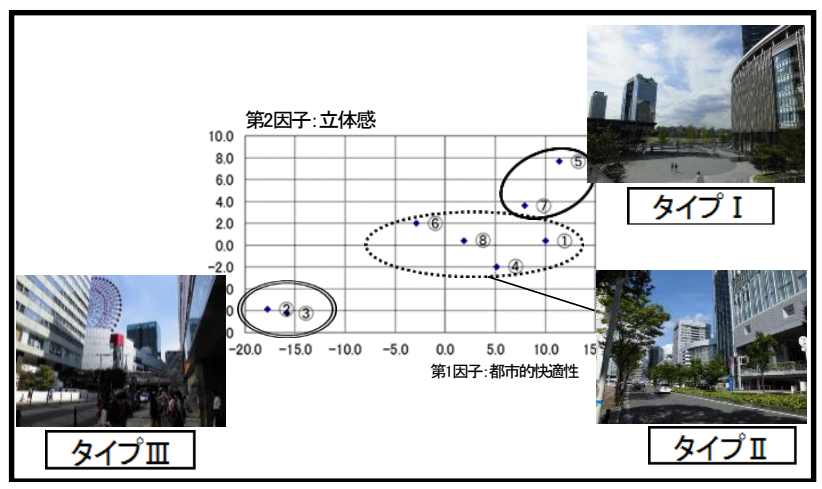

図-3 因子得点の 2 次元布置図（梅田）

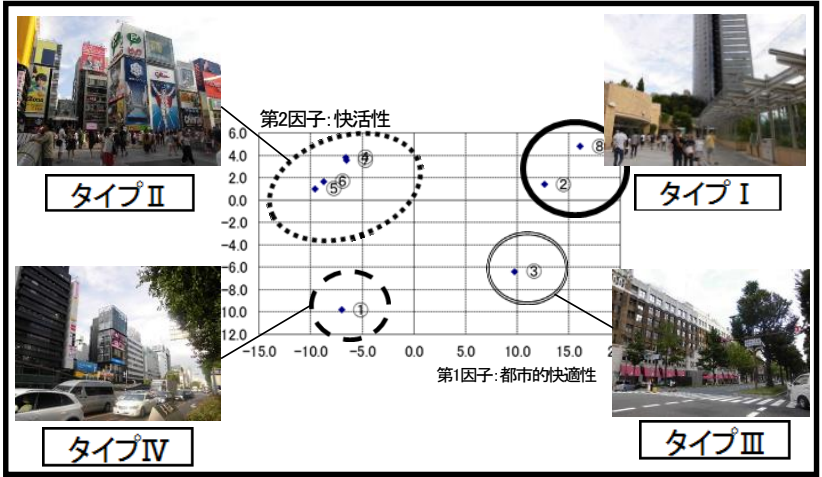

図-4 因子得点の 2 次元布置図（難波）

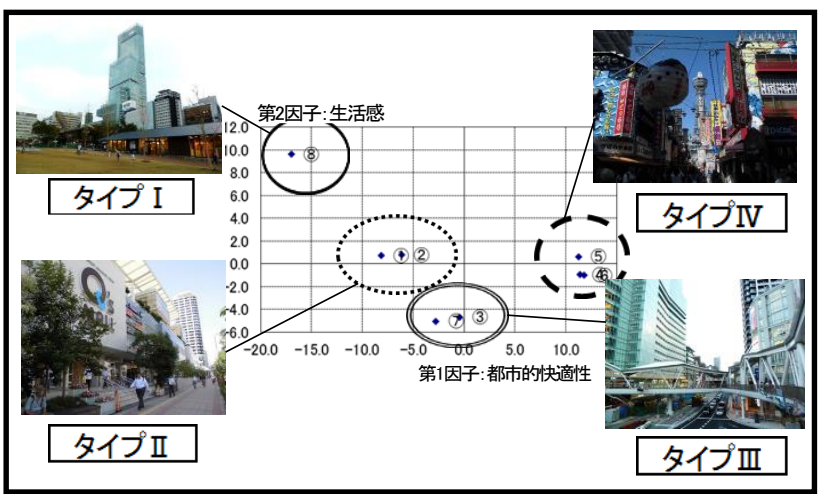

図一 5 因子得点の 2 次元布置図（天王寺） 
開放感と快適性をもたらしている。IVは快適性及び活気と 賬わいに乏しいタイプであり、統一したスカイラインを形 成しているが建物の密集感は強く、植栽の存在感は弱い。

難波エリアは更新年代や用途、高さが異なる建物が混在 し、雑多な印象がある。主として人やモノの密集度が高く、 活気や賑わいを伴う景観が多いが、新しく整備された景観 では快適性も認められるなど、全体的な評価を一様に表す ことは難しい。しかし、煩雑さと落ち着き、圧迫感と開放 性、というような対照性を同一エリア内に散乱して含んで いること自体が、難波らしさであると考えられる。

\section{（3） 天王寺らしさの解明}

天王寺エリアにおいては、主に 1994〜2015 年の約 20 年 の間に全体の 6 割以上の建物が更新され、同エリアではこ の期間、阿倍野地区第二種市街地再開発事業と阿部野橋夕 一ミナル整備構想を中心として様々な開発事業が継続的に 行われている。また、JR天王寺駅及び近鉄阿部野橋駅周辺 に高層の商業系施設が集中して存在する一方で、その周辺 には低層の住宅系用途が分布しており、ゾーン区分がなさ れている。また $300 \mathrm{~m}$ 以上もの高さを誇るあべのハルカス が突出してランドマーク的な存在感を放っている。天王寺 エリアでは主に、再開発事業によってターミナル駅周辺の 景観に変化が生じ、高層・超高層建築からなる都市的景観 と、1993 年以前加残る住宅系用途の低層建築功なる景 観とが、空間的に住多分けられているといら特徵が見られ る。また、エリア内に天王寺公園という都市公園を含み、 大規模な緑地が都心に隣接しているという特徵も見られる。

因子分析の結果、第 1 因子を『都市的快適性』、第 2 因子 を『生活感』と判断し、8 景を 4 タイプ( I IV)に分類でき た (図 5)。I は快適性を備え、良好な生活空間を伴うタイ プであり、地面を覆う芝生と低い位置に見える空が、広が り感と潤い性をもたらしている。IIは適度な快啇性と生活 感を伴うタイプであり、設置物や広告物、人が多く見られ、 ヒューマンスケールな界隈性が生活空間イメージを助長し ている。IIIは適度な快適性を保つが、生活感を欠いている タイプであり、歩道橋等の様々な建造物が画面の半数以上 を占め、人工的な印象が目立つ。IVは快適性に乏しいが、 生活感を伴うタイプであり、商品・ワゴン等の設置物や広 告物が非常に多く、高い賑水い性が見られ、建物高さや構 造が大都市イメージを遠ざけている。

天王寺エリアでは、全体的に生活感が蚛調される。一方 で都市的快適性という点では、開発・更新年度に対して強 い関連性が見られ、同エリアに元来形成されていた生活感 あふれる景観の一部が、近年の再開発事業等によって都市 的景観に変化していると言うこともできる。商業・業務系 の都市空間と生活空間が空間的には住多分けられている一 方で、イメージとしては共存しているところに、天王寺ら しさが形成されていると推察される。また天王寺エリアは、 のどかさや自然性の不足を指摘されているが、“てんしば” として生まれ変わった天王去公園という都市公園の存在が
これらを補填し、新しい地域イメージが創出されつつある。

4, まとめ

大阪市の主要 3 エリアは、近年の大規模な開発によって 景観的に刷新されている。更に地域イメージに関する意識 調査においては、3 エリア全ての第一因子が「都市的快適 性」であり、開発事業による刷新が開放感や植栽による潤 いの助長など、人々に都市的な快適性を感じさせる景観を 形成している。第 1 因子が共通していたため、3 エリアの 地域特性を示しているのは、第 2 因子と考えられる。梅田 エリアは「立体感」によって表現されているが、この立体 感は、印象的な評価というより空間構造に影響される評価 と言うことができ、開発事業によってもたらされる都市的 快適性は備えているものの、地域イメージとしての「梅田 らしさ」を必ずしも正確に表現するものではないと推察さ れた。難波エリアは「快活性」によって表現され、活気や 賑わいを伴う景観に「難波らしさ」を見出すことができ、 このような景観を含む区域が観光地としての集客効果を上 げている。天王寺リアは「生活感」によって表現され、 再開発事業による景観変化が多数見られるが、難波エリア の様な観光地としての活気・賑わい性ではなく、人々の生 活空間としての温か夕が強調されているところに「天王寺 らしさ」を見出すことができた。また、天王寺エリアは再 開発による刷新という意味で未だ発展途上と言うことがで き、あべのハルカスの開業を始めとして、今後都市空間と しての性格を強めていくことも考えられる。

以上のように大阪市の主要 3 エリアはそれぞれ異なる景 観特性をもちあわせ、個性豊かな地域が混在していること が大阪市の地域らしさであると言える。観光都市としての 性格を強める同市の今後のまちづくりに際しては、個々の 地域の個性を活か寸ことが必要と考える。また本 3 ターミ ナルを繋ぐ他地域の “らしさ”を発掘し、市内をネットワ 一ク的に訪問することで得られる大阪らしさを感じ取れる 物語性を構築していくことが、今後の課題と考える。

\section{引用・参考文献}

1)大阪市(2015) : 今後の景観施策のあり方について

2)ケビン・リンチ(1968) : 都市のイメージ, 岩波書店,276p

3)木下勇,ハンス・ビンダー(2011) : 日本の都市再開発におけるアイデンティ ティと持続可能性について:日本都市計画学会都市計画論文集 46(3),463-468 4)木村冓維子(2014) : 人びとの記境から読み解くアイデンティティを育むコ ミュニテイ䤑成空間としてのコモンに関する研究一阿佐ケ䧾宅における” 市民の庭”としてのコモンを事例として: 日本都市計画学会都市計画論文集 49(3),681-686

5)倉澤知久,十代田朗;津々見崇(2013): 旅行杂隺誌にみる町並み観光地のイメー ジの変遷と地域特性とお関連に関する研究: 日本都市計画学会都市計画論 文集 48 (3), 1095-1100.

6) 鈴木崇之,石川徹,貞広幸雄浅見泰司(2011) : 都市施設が居住者のまちへの 愛着に及ぼす影響に関する研究 : 日本都市計画学会都市計画論文集 $46(2), 117-123$ 